\title{
Australia's Long History of Immigration, Policing and the Criminal Law
}

Mark Finnane (Griffith University) and Andy Kaladelfos (University of New South Wales)

\begin{abstract}
Modern immigration is a highly regulated procedure governing the mobility of peoples between sovereign jurisdictions. This procedure has been progressively refined since the late $18^{\text {th }}$ century through mechanisms of government that have frequently deployed the apparatus of criminal law. In this chapter we examine the long history of the intersection of criminal law and policing regimes in the service of immigration control in Australia. We take the Australian case as exemplary rather than exceptional. The particular conditions of British settlement of the convict colonies and the later construction of the White Australia Policy constitute a particular local formation of a more general phenomenon found in the development of modern states. Through a brief history of Australian immigration law and policing we highlight both the long-standing criminalisation of migration regulation breaches, and the persistent governmental concerns with the exclusion of undesirable populations, especially of those with criminal records. In the light of these histories we question the assumption that 'crimmigration' is a peculiarly late modern convergence of criminal law and immigration regulation.
\end{abstract}

\section{Keywords}

immigration policy, immigration law, criminal law, Australian history, policing, customs, border control 


\section{Introduction}

The contemporary development of the 'crimmigration' thesis has been characterised by criminological, sociological and legal research highlighting a contemporary crisis or transformative moment in the deployment of criminal law for the purpose of punitive immigration control. In this chapter we argue that the 'crimmigration' neologism underestimates the long history of immigration controls intersecting with criminal law and policing regimes. While Australia is the focus of our analysis, we propose that the Australian story is not exceptional but rather exemplary, with international research on the history of twentieth century immigration law and policy showing governance of immigration as a cornerstone of national security and domestic policing.

These themes will be explored through a contextual analysis of Australian immigration law and its policing from colonisation to the second half of the twentieth century. Given the emphasis of the 'crimmigration' thesis on criminalisation we focus on the history of criminal offending as a barrier to immigration, on the criminalisation of unapproved entry, on the punishments and exclusions embraced by immigration statutes, on the policing of the associated powers and on the legal struggles around these powers and thresholds. We suggest 'crimmigration' is a tautology, since no regime of immigration governance in the modern state was ever separate from the legal and policing mechanisms that enabled its administration.

\section{The 'Crimmigration' Thesis}

According to Juliet Stumpf empirical, practical and theoretical research 'have revealed at least three larger insights . . . First, that the crimmigration convergence is impacting how governments and others perceive and approach migration; second, that crimmigration control is bound up with issues of ethnicity; and third, that crimmigration control has called into question the fundamental nature of criminal law'. ${ }^{1}$ Others agree, questioning the use of criminal law enforcement of immigration controls. In the words of Aliverti, it is 'a disruption of the principles of certainty, equal treatment, harm to others and proportionality'. ${ }^{2}$ Aliverti

\footnotetext{
${ }^{1}$ Stumpf, 2014, p. 245.

2 Aliverti 2012, p. 426. More recently Aliverti has extended this set of objections to examine especially the significance of the increasing use of strict liability underlying many contemporary British immigration offences: Aliverti, 2017 and see also generally Aliverti
} 2015. 
argues against the widespread use of criminal law for the prosecution of immigration offences on the grounds that criminal law and punishment should be reserved for the most serious offences and that immigration offences are victimless and have a low degree of harm.Alverti highlights what she sees as a contrast between a European 'administrative law' treatment of immigration and the use by Britain of 'criminal sanctions to deter immigration law-breaking', positioning the differences with frameworks of legal philosophy on the function and scope of the criminal law. ${ }^{3}$

Scholars such as Stumpf and Aliverti have made important contributions to understanding the scale and significance of contemporary immigration and refugee policy and practice through these perspectives and others generated by researchers deploying the concept of crimmigration. The concept has generated new and innovative research and ignited scholarly discussion of this pressing social policy and humanitarian problem in many Western nations. Reading this literature however, one is struck by the dissonance between social science researchers (whether from law, sociology, criminology, political science, international relations) and historians in identifying and understanding the conditions that have led us to this point. As so often, historians encounter these contemporary phenomena less with a spirit of alarm than of recognition - a recognition of the pathways that have led us here and their long development, rather than seeing 'crimmigration' as a sudden schism in policy focus. ${ }^{4}$

In response to this dissonance, our chapter reflects on the history of immigration in Australia, not so much to point out simply that these things have happened before but rather to consider the possibility that criminal law and immigration law require each other, and that talk of their convergence is distracting more than illuminating. On this question, legal scholar Lucia Zedner has pointedly asked whether 'the criminal law [is] only for citizens?' In doing so, Zedner highlights the criminal law's very bounded nature, and its tendency to social exclusion by drawing attention to the controversial concept of 'enemy' criminal law distinguished from the

\footnotetext{
${ }^{3}$ Aliverti, 2017, p. 376. While this is not the place to explore the history of European law, it is worth noting that administrative law commonly involved an expansive use of the police power of the state from the nineteenth century onwards, and that in German states illegal migration was regarded as a crime: see eg Fahrmeir, Faron and Weil, 2003.

${ }^{4}$ For a more nuanced social science view of the evolution of immigration policy as 'adaptation' in an administrative and political context see Slaven and Boswell, 2018
} 
criminal law that exists for citizens. ${ }^{5}$ This tendency of the criminal law is inherent in the concept of criminal jurisdiction in itself, defining the limits of jurisdictional reach to particular populations.

In addressing these questions we suggest that the concern expressed about erosion of fundamental principles of criminal law relies on too abstract and idealised a notion of criminal law as dealing with only serious offences, and perhaps even being an instance of too much resting on a general thesis of increasing criminalisation. ${ }^{6}$. With the history of Australian immigration policy and policing in mind we suggest that the crimmigration thesis requires a revision, especially with respect to its claims of a recent and intense convergence between criminal law and immigration law. Our review also seeks to open up a question that crimmigration researchers must confront, namely the need to address policy and practice in border control and immigration policy in a way that recognises both the political constraints of democratic politics and the constitutional realities of a world of sovereign states. If these legal intersections have such a long history, we need new imaginations of the law and governance to revolutionise state approaches to immigration.

\section{Governing Immigration in the Long Nineteenth Century}

Modern Australian history is a settler history, that is, an immigrant history. A number of elements of that history in just the first century or so after colonisation in 1788 are relevant to the subsequent history of immigration policy and regulation. First and most important immigration was across the seas. Only to a very limited degree were colonial borders porous. Geographic realities constituted an economic and physical barrier to mass mobility across Australian continental boundaries. Arrival by boat entailed already complex regulation and documentation of passenger movement, whether for convicts early on, or for free settlers, no matter if they were assisted or unassisted immigrants. One consequence is that passenger movement in and out of Australia in the nineteenth century is very well recorded. Already in this reality we see evidence of the 'transversal' phenomenon, described by Sharon Pickering and Leanne Weber, which seeks to highlight the policing of immigrants even before they reach

\footnotetext{
${ }^{5}$ Zedner 2013, pp.49-50.

${ }^{6}$ Farmer 2016; Lacey 2009; Lacey 2018.
} 
national borders. ${ }^{7}$ Passenger movements into Australia took place during the century when merchant vessels were increasingly subject to regulation. Shipowners and vessel masters had particular obligations for the care and control of their passengers. This fact made them valuable conscripts in the enforcement of cross-border people traffic, and the subjects of fines and other punishments if they did not comply with regulations. For example, when the Australian colonies in the 1880 s came to restrict the movement of Chinese passengers, the mechanism chosen to enforce this policy was to oblige a ship's captain to limit the number of Chinese passengers per weight of vessel or be subject to very onerous disembarkation charges per excess passenger. ${ }^{8}$

Criminal law policy and practice were a significant aid to the control of colonial borders both from across the seas and within the Australian continent. We can see these links from two examples. The first was the power of detention, under criminal charge, with penalties of imprisonment, fine and deportation, exercised against non-British subjects, especially Asians, under the increasingly restrictive colonial immigration laws. The New South Wales Chinese Immigrants Regulation and Restriction Act, 1861 (No 28a. s. 10-12), stipulated that if a Chinese person did not pay the tax of ten pounds to enter the colony, they would be apprehended and placed before the petty sessions and ordered to pay the penalty. It is important to acknowledge that these were mechanisms for regulation of immigration traffic rather than complete prohibition on entry. This difference was highlighted by the successful appeal of two Chinese appellants in the late nineteenth century, who challenged charges brought against them as illegal immigrants under the Western Australian Immigration Restriction Act, 1897 (an Act which introduced a dictation test and set out a range of 'prohibited immigrants' - many categories of which were reproduced in the Commonwealth government's Immigration Restriction Act, 1901, known as the 'White Australia Policy'). Their appeal against conviction succeeded on the grounds that the Western Australian legislation under which they had been detained did not apply to Chinese subjects who were covered by previous legislation governing but not prohibiting Chinese immigration. ${ }^{9}$ Importantly, as Mountford has compellingly documented, late century immigration control was managed within a larger geopolitical context, not only of intra-imperial but inter-imperial interests, that is of relations between the

\footnotetext{
${ }^{7}$ Pickering and Weber 2013.

${ }^{8}$ Markus 1979; Mountford 2016; Finnane 2014.

${ }^{9}$ Finnane 2013b.
} 
colonies and the colonial office, and of relations between the British and Chinese governments. ${ }^{10}$

A second set of controls, with heavy penalties, was exercised against those with criminal records who attempted to enter the colonies or to cross from one to another. There were two flurries of statutory reform along these lines, at mid-century and at the turn of the nineteenth century. In the $1850 \mathrm{~s}$, concern over the flood into Victoria of ex-convicts from Tasmania was the impetus for legislation to control their entry. ${ }^{11}$ The Victorian Influx of Criminals Prevention Act 1854 provided that a person who had arrived in the colony of Victoria and could be shown to have been transported within the previous three years would be asked to leave the colony. If they did not comply, they would be subject to removal from the colony or three years' imprisonment for males and one year for female prisoners, along with other punitive measures including the removal of personal property. The provisions were to be carried out by justices of the peace at the petty sessions and by constables who had the power to arrest and board vessels to inquire about immigrants. Again in the 1890s and early 1900s a number of states or colonies criminalised the cross-border movement of habitual criminals, escaped convicts and even those with simply a conviction record. ${ }^{12}$ In 1901, for instance, vagrancy charges were used to imprison a group of Algerian men who had landed without documentation in North Queensland, a proceeding that would lead to their eventual extradition to New Caledonia. ${ }^{13}$ In this instance, petty offences, the day-to-day business of the criminal law, were employed to deal with this border problem. The same was true of other colonies where vagrancy laws assisted in controlling immigrants, for example in the colony of Mauritius. ${ }^{14}$

The wide remit of vagrancy laws allowed for their employment in managing so-called problem populations, with immigrants and immigration being just one group managed through these regulations (others included the homeless and homosexuals). In implementing immigration controls, the statues imposed by the Western Australian government and later the Commonwealth government contained wide provisions for prohibition on the basis of various kinds of conduct. The conduct was not just that deemed 'criminal' by the law but conduct more

\footnotetext{
${ }^{10}$ Mountford 2016; Martens 2006.

${ }^{11}$ Petrow 2012.

12 Bergantz 2018; Speedy 2016.

13 Speedy 2016, p.20.

${ }^{14}$ Kimber 2013.
} 
widely deemed disrespectful to social morals. These included the provision in the Western Australian Immigration Restriction Act 1897 of an immigration prohibition on the basis merely of a 'misdemeanour involving moral turpitude' (Section E). Both the Western Australian and the Commonwealth Acts included a prohibition on sex workers, deeming 'a prostitute or any person living on the prostitution of others' a prohibited immigrant. In 1936, Mabel Freer, an Indian-born white British subject was denied entry and declared a prohibited immigrant after she was given the dictation test in Italian, which she failed. Freer's exclusion was based upon concerns over her sexual morality, as the Australian partner she had travelled with was not yet divorced from his previous wife. ${ }^{15}$ Conduct perceived as immoral, although not necessarily criminal, has long been linked to the regulation of immigration in Australia.

The regulation of general immigration in the nineteenth century required a high degree of involvement of the private sector as it would now be called, while the regulation of crossborder criminal movement was the special responsibility of public policing. This latter obligation drove innovation in policing. New technologies of intelligence sharing were encouraged by the need to keep track of undesirable immigrants. In the 1880 s continuing escapes of French convicts from the penal settlement of New Caledonia prompted colonial police in Queensland,New South Wales and Victoria to consider the adoption of new methods of criminal identification and intelligence sharing. A few years later similar concerns about the need to track undesirables shaped a cross-border agreement between Australian state policing agencies to develop fingerprinting systems and share such information through a central registry based in New South Wales. Close links between what were seen as the challenge of mobile criminal and suspect populations in the development of new policing and border control technologies (the passport above all) characterised the turn of the twentieth century. ${ }^{16}$

Police systems of tracking prohibited immigrants were well developed by the twentieth century. In the year 1907 the NSW Police Gazette circulated advice about dozens of warrants issued for the arrest of prohibited immigrants. Most of the warrants were for the arrest of those who had deserted from vessels that had arrived in Sydney Harbour. Under the headline 'Breach of the Immigration Restriction Act' these bulletins, circulated to NSW domestic police stations,

\footnotetext{
${ }^{15}$ Frances 2007, pp.243-244; Stewart, Hohmann, and Robertson 2005. For similar prohibitions and sanctions in US immigration law and policing, see Rosenbloom, 2016.

${ }^{16}$ Finnane and Myrtle 2011; Cole 2001; Rodriguez 2006; Torpey 2000.
} 
described the name, appearance and background of the 'prohibited immigrants'. Akbardeen Futta was one such immigrant who had a warrant issued for his arrest in October 1907. He had absconded from the ship R. M. S. 'Mooltan' in Sydney. Futta was described as 'about 30 years of age, medium height, rather thick-set, round race, black beard, whiskers and moustache; a native of the Punjab, India'. ${ }^{17}$ Later police gazette descriptions would be accompanied by photographs, and during the wars - as discussed in the next section - police gazettes contained notices of escaped war criminals (such as four Italians who escaped Marrinup Camp in Western Australia, 1943). ${ }^{18}$ The regulation of immigrants and immigration was not the exclusive domain of a national security or immigration department. From early on, policing borders and national security involved a range of different criminal justice apparatus (police, magistrates, customs) as well as the wide use of many provisions of the criminal law. These regulatory and policing regimes were already deeply implicated in the nation-forming work of Federation in the 1890s and in the new Commonwealth after 1901. A foundation stone of the Commonwealth was immigration restriction provisions, including the creative use of the dictation test, and penalties attached to breaches of the Act. But the means of implementation were those of bureaucracy, an apparatus backed by the criminal law and domestic policing of immigration control at Australian ports. ${ }^{19}$

\section{Enemy Aliens and Suspect Populations in the Early Twentieth Century}

As in other countries engaged in the conflict, the First World War initiated very significant changes in surveillance and inspection of non-citizens. The large-scale migrations of the nineteenth century had left a legacy of sizable populations of immigrants, and not only in settler countries: Britain and France in particular had long histories of asylum for political refugees from authoritarian states in other parts of Europe. The outbreak of war soon rendered some of these vulnerable to close attention from the authorities, especially as wartime legislation extended the reach of policing into the lives of suspect communities. In Australia, which hosted significant cohorts of German immigrants, especially in Queensland and South Australia, the War Precautions Act, Commonwealth (1914) and associated regulations soon rendered many

\footnotetext{
${ }^{17}$ NSW Police Gazette, Sydney: Office of Inspector General of Police. 30 October 1907, p.377.

${ }^{18}$ WA Police Gazette, Perth. Government Printer. 15 September 1943, p. 386.

${ }^{19}$ Day 1996; Finnane $2013 a$.
} 
such people into precautionary internment. ${ }^{20}$ The Act allowed for the prohibition on immigration and deportation of aliens, a serious consequence for some living in Australia at the time. Through wartime regulation and its consequences an alien subject's status in Australia became criminalised, with their criminalisation enforced through powers of arrest, detention and punishment.

The mechanisms of immigration control were refined institutionally and legislatively during this period. Executive discretion was virtually untrammelled, not surprising during war-time but more so in the First World War than in the Second. Aliens were vulnerable to administrative expulsion. Political dissidents, even if British citizens, who were originally exempt from the Act when introduced in 1916, were vulnerable to the deportation discretion exercised under the amended Unlawful Associations Act, Commonwealth, 1917. ${ }^{21}$ Associated with the threat from a country's external enemies was the challenge, real enough in many cases, from internal dissidents and opponents of Australia's participation in the war. The position of political dissidents who had been born outside Australia, even if they were British subjects, was especially vulnerable. The deportation of Father Jerger, parish priest from Marrickville in Sydney, is a famous example of the risks facing the German-born; even those like Jerger who believed that having a British father would have resulted in British status. ${ }^{22}$ Another wellknown example is that of Tom Barker, a radical socialist who was convicted in Sydney of membership of the Industrial Workers of the World (IWW), whose incarceration prompted furious protest from his associates and who was later deported in spite of his English birth. ${ }^{23}$

As Barker's deportation papers and subsequent surveillance illustrate, tracking the movements of the undesirable involved information networks linking military intelligence, police departments, and the government agency charged at this time with border management, that is the customs and excise department and its officers. ${ }^{24}$ As described above, prohibited immigrants, such as Chinese seamen deserting their ships while in port, were regularly advertised in the pages of the domestic police gazettes circulated to stations, frequently by this

\footnotetext{
${ }^{20}$ Fischer 1989.

${ }^{21}$ Nicholls 2007, p.54

${ }^{22}$ L'Estrange n.d.; Henderson 1976

23 Turner 1969; Burgmann 1995.

${ }^{24}$ Day 1996; Cain 1983.
} 
time with their photograph. People like Barker who had been deported following even a lower level criminal conviction, would likely have left not only a photograph but a fingerprint record. This biometric data was maintained in central police registers and circulated for information to port officials with instructions to bar entry to such people, as Barker's intelligence file attests. ${ }^{25}$ Thus the links between criminal law, administrative, law, criminal justice and immigration were an effect of statute and regulatory process. The organisations responsible for arrest and conviction of immigrants were primarily criminal justice oriented - state police department, petty sessions magistrates, and federal government bodies who worked closely with customs and other organisations.

Criminal conduct and political dissidence were not the only grounds for sanction in this early twentieth century immigration control regime. Governmental parsimony as well as racial anxieties informed the provisions for restricting entry and sanctioning deportation of those failing to meet the requisite health standards. ${ }^{26}$ Like the earlier colonial statutes, the federal government's Immigration Act (1901) and the Quarantine Act (1908) together acted as a barrier to immigration of those with physical and mental health conditions, with similar policing mechanisms in place, including the use of domestic health screenings and ship master's lists to identify 'undesirables'. ${ }^{27}$ As scholar Jean P. Smith has shown, in Australian deportations of British-born citizens for alcoholism or mental illness, the exclusions of the White Australia Policy were many and varied, and could apply equally to white British immigrants as they could to those from other racial backgrounds. ${ }^{28}$ Deportation in this context, writes Smith was 'social engineering in the British empire'. ${ }^{29}$ The principal objective of the 1901 Immigration Restriction Act was famously the advancement and protection of a White Australia. The statutory mechanisms, especially the dictation test, and their administration, had their rationale in the need to balance Australia's standing as a sovereign state with its membership of an empire of diverse peoples, as well as the need to manage international obligations. ${ }^{30}$ For these reasons there were always exceptions to prohibited entry and subsequent risk of criminalisation

\footnotetext{
${ }^{25}$ Barker 1919.

${ }^{26}$ Bashford 2004; Bashford and Strange 2002.

${ }^{27}$ Bashford and Howard 2004.

${ }^{28}$ Smith 2018; Bailkin 2012; Bashford 2002.

${ }^{29}$ Smith 2018, p.505.

${ }^{30}$ Lake and Reynolds 2008.
} 
- but if deportation is regarded as punishment, a sanction exercised against those who fail to meet the membership criteria of a particular political community, then this was a regime which operated with a very regular application of its reach.

In the 1920s and 1930s, however, few people were deported for criminal offences, and most of these were for offences by British-born immigrants. In 1926, for example, there were 34 deportations for criminal offences, 30 of them British people. ${ }^{31}$ One high-profile example from the 1920s was the deportation of a British assisted immigrant Leonard Henry Puddifoot, convicted at the age of 17, of the sex-motivated manslaughter of a 5-year-old boy in 1923 and sentenced to a mere 3 years' imprisonment. Puddifoot's sentence was a scandal at the time, leading to a range of calls for heavier penalties against sexual offenders, with crimes of this type understood through the language of eugenics as caused by 'degenerates', and vigilance committees of parents seeking to protect children from crime. Puddifoot was later revealed to have a family history of mental illness, and questions were raised about why he was allowed through immigration screening. ${ }^{32}$ As one NSW politician, Dr Robert Stopford, told a town meeting in 1923 to loud applause: 'Australians do not want him here'. ${ }^{33}$ Puddifoot was subsequently deported in late 1925 at the expiration of his sentence. ${ }^{34}$ In the 1920s and 1930s the deportation power for criminal behaviour was mostly used to remove British-born migrants convicted of serious criminal offences, like Puddifoot. The Puddifoot case, too, shows the overlapping nature of the various regimes of control and population regulation - domestic policing and national security, criminality, public health and immigration control.

The earlier enactment of wartime restrictions, and the associated institutional creativity, consolidated the immigration regime as a central element of national defence. This was to become clear in the interwar period, again not only as a particularly Australian phenomenon but shared with other nations both settler and theEuropean homeland. The value of immigration control as an element of national defence was highlighted by the post-World War 1consolidation of national institutions of intelligence and policing directed towards maintenance of increasingly sharply defined criteria of national membership and belonging.

\footnotetext{
${ }^{31}$ Nicholls 2007 p. 63.

${ }^{32}$ Kaladelfos 2010.

${ }^{33}$ Kaladelfos 2010 p. 258.

${ }^{34}$ Puddifoot 1925. National Archives of Australia: SP42/1, C1925/10865. Leonard Henry Puddifoot [Box 179].
} 
The war had stimulated the refinement of domestic political intelligence as part of a nation's system of military intelligence. This may have been less true of Australia than elsewhere-in Canada the old Dominion police was wrapped into the transformed Mounties to become the Royal Canadian Mounted Police; in Britain domestic intelligence was consolidated forever after in the establishment of MI5; in France, where international immigrant policing was most intense, in the transformed intelligence and policing capacity of the prefecture of police in Paris; in the United States in the consolidation of the FBI into a major instrument of federal policing. ${ }^{35}$ The Australian picture was mixed. A federal (that is, Commonwealth) police was established in 1917 but was minuscule in power and importance for decades after; intelligence policing was however much more significantly associated with interwar policing of immigrant communities as well as political dissidents, in the Commonwealth Investigation Branch of the federal attorney general's department. ${ }^{36}$

Hence immigration control was a divided responsibility in Australia in the interwar years. In the aftermath of the First World War the state police forces, the real powerhouses in Australian law enforcement at this time, would have preferred to maintain their power over immigrants through a retention of alien registration, but only on condition that the Commonwealth pay for it. When the Commonwealth refused to do so, the states had to make do with their standard approach to intelligence, which was largely determined by collection of information associated with crime investigation. The result may be described as control with a high degree of discretion vested in state police, hampered by limited information about those they were expected to police. ${ }^{37}$ Certainly the extent of immigration controls in the interwar period was much less complete in Australia than the very ambitious comprehensive registration programs adopted in Europe, especially in France. ${ }^{38}$

What made Australia distinctive was the relative efficiency of management at the borders, occasionally breached by illegal arrivals such as the deserting Chinese seamen arrested in large numbers at Fremantle in 1927, or a similar group the target of immigration authorities after

\footnotetext{
${ }^{35}$ Rosenberg 2006; Ngai 2004; Whitaker, Kealey, and Parnaby 2012; Andrew 2009; Weiner 2013; Rosenbloom 2016.

${ }^{36}$ Cain 1983; Dutton 1998, 2002; Finnane 2009.

${ }^{37}$ Finnane 2009.

${ }^{38}$ Rosenberg 2006.
} 
they decamped in the wake of the Japanese invasion of China in 1937. The White Australia policy was at its peak, but even so the country was not free from travel by otherwise restricted groups, with significant numbers of Asian tourists and students and business people making their way into and around the country during this period. ${ }^{39}$ Those who evaded controls were vulnerable to the attention of state police as well as officers from the very active Commonwealth Investigation Branch, always on the lookout for subversives and dissidents. Both policing and intelligence agents were sources of information provided to as well as receiving advice from the customs and excise department.

Deportation was refined in the interwar years as a sanction whose application nevertheless remained something short of untrammelled executive discretion. The interplay of criminal law and the administrative law embodied in the immigration statutes was at play crucially in 1923 in the deportation of two Irish republican 'envoys' on charges of sedition. Their deportation defined Australia's immigration powers outside wartime and reflected the intra-imperial political desire of quelling Irish republicanism. In the case of the envoys, the High Court decision affirmed the federal government's deportation power of British subjects not resident in Australia. The case solidified the use of immigration powers for the purposes of national security. ${ }^{40}$ Somewhat surprisingly such mechanisms had not been developed in more than two decades since the enactment of the original immigration statute. The sensitive issue of deportation of British citizens resident, but not born in Australia, was also adjudicated in this decade by the High Court. In this instance, the court rejected the attempted deportation of a troublesome, long-term resident of Australia, the(British-born) trade unionist Tom Walsh in 1926. In doing so, the court established the notion of absorption into the community as a threshold protecting immigrants from the risk of deportation (Re Yates; Ex parte Walsh [1925] HCA 53). In the judgement of Knox CJ and Starke J: 'A person who has originally entered Australia as an immigrant may, in course of time and by force of circumstances, cease to be an immigrant and become a member of the Australian community, exempt from the operation of the immigration power'.

If British-born residents were vulnerable to the whims of immigration law and politics, the position of non-British immigrants was perilous. Ethnicity was closely associated with

\footnotetext{
${ }^{39}$ Kuo and Fitzgerald 2016; Finnane 2010.

${ }^{40}$ Finnane 2013a.
} 
calculations of threat, and the efforts of both police and intelligence agencies were directed to maintaining a stable community in a white Australia. Yet other than straightforward breaches of the Immigration Act, occasions for intervening, prosecuting, punishing or deporting suspect aliens generally waited on a perceived political threat. The most famous deportation crisis of the 1930s was the struggle over the attempted visit of the Czech Communist and peace activist Egon Kisch ( $R v$ Carter; Ex parte Kisch ('Kisch's case') [1934] HCA 50). ${ }^{41}$ Later in the 30s, concern over fascist and Nazi sympathisers among Italian and German immigrant groups stimulated the attention of the Commonwealth Investigation Branch. ${ }^{42}$ In all of these instances, we see once again the close links between domestic police, national intelligence agency and the Commonwealth Customs Department which was responsible for immigration and border control in ways that make it difficult to separate the operations of the criminal law, immigration law and national security.

\section{The Second World War and Post-War Mass Immigration}

As in the previous war, the Second World War produced new institutions for the management of the population, but this time also proved to be the stimulus for a massive and nation-altering change in policy towards immigration. The conditions of total war highlighted the challenge of dealing with immigrant populations drawn from the homelands of enemy states. But the devastation of war provoked a rethink of the categories within which the national government would plan for population growth as a remedy for the economic stagnation that had afflicted the 1930 s. ${ }^{43}$

While the policing of immigrants in the Second World War was primarily the responsibility of state police, their activities were increasingly tied to national priorities through the development of a new Commonwealth security apparatus. This agency was closely linked to military intelligence, but its establishment set the country on a path towards a civilian domestic intelligence agency in the post-war period. The Commonwealth Security Service as it was known was headed variously by a state police commissioner and then a judge during its first few years, signalling the separation from military intelligence. As in the previous war,

\footnotetext{
${ }^{41}$ Zogbaum 2004.

42 Dutton 2002; Cresciani 1980.

${ }^{43}$ Tavan 2005; Macintyre 2015
} 
internment of identified enemy aliens, mainly German, Italian or Japanese born, was adopted as a measure of control of the immigrant suspect communities. The operation of internment at this time was tempered by a more considered process of review through a civilian aliens classification committee which included political, bureaucratic and legal representatives. ${ }^{44}$

The Australian government's post-war immigration policy transformed the approach to immigration from the earlier ethos of containment and close control to a more open and nationbuilding enterprise. This fundamental shift in political and cultural orientation set the scene for mass immigration as a continuing feature of Australian social and economic policy down to our own time. What implications did this change have for our consideration of the links between criminal law and immigration law? The federal government was now enthusiastically embracing immigration, but the policy sought to manage only that immigration compatible with the overall objectives of the White Australia policy. In practice however, the British preference of immigration policy was put under pressure by two realities. One was the shortfall in British immigrants available and willing to come to Australia. The second was the international crisis provoked by the very large population of displaced refugees in Europe in the wake of the war. Australian immigration policy developed as an approach accommodating a growing range of population backgrounds managed within a hierarchy of preferences. Crudely these placed British at the top, followed by non-British Europeans especially northern Europeans, with eastern and southern Europeans following and severe restrictions on the admission of Asian immigrants. ${ }^{45}$ To manage this range of political objectives, the Labor government in the early years of the post-war period maintained the use of deportation to remove from Australia groups of Asian residents who had sought refuge during the war and were expected now to return to their own countries. Significant political conflicts developed around many of these cases, ending in the High Court in some famous instances. ${ }^{46}$

What calculations of domestic and national security risk were tied to this nation building exercise? Faced with the imminent arrival of hundreds of thousands of new immigrants the state police forces were initially very apprehensive, warning the federal government even before the end of war of the challenges that might lie ahead in managing criminality and other behaviours expected of people traumatised by war. Yet proposals for mass registration of alien

\footnotetext{
44 Saunders 1992; Finnane 2007; Neumann 2006

${ }^{45}$ Persian 2017.

46 Tavan 2005; Neumann and Tavan 2009; Neumann 2004, 2015.
} 
immigrants by the state police forces were rejected by the Commonwealth, whose first Minister for Immigration, Arthur Calwell, planned a more welcoming reception for people who were refugees from totalitarian governments. Consequently, police, both state and federal, as well as the intelligence agency, ASIO after 1949, were kept at arms distance by the very powerful Immigration Department during the first 15 years of post-war immigration. ${ }^{47}$ These divisions constituted the formal arrangements. The reality was that immigration could not proceed without both police and intelligence becoming involved - state and federal. After the formation of the domestic intelligence agency, ASIO agents vetted as far as possible the backgrounds of displaced persons in the European-origin migrations of the 1950s. Domestic police were closely involved with the reception and integration of the immigrants once they reached Australia, necessarily so if they committed crime or otherwise came to police attention as victims of crime or fatalities in accidents.

Criminal justice and criminal offending became closely linked to the politics of immigration in the 1950s in unique ways. The interlinking followed popular press and opportunist political agitation by the New South Wales Labor government claiming that immigrants were responsible for crime waves. The strongly assimilationist policy of the Commonwealth government, with its agencies encouraging absorption of the immigrants as 'New Australians,' resisted state Labor's imputation that immigrants were criminals or more likely to be criminals. The federal government was enabled to combat the spurious state allegations of excessive immigrant criminality through the intensive surveillance of the immigrant population already being conducted by state police. The state police forces were conscripted into the cause of statistical combat, acting at the request of the Commonwealth Immigration Advisory Council, which established a committee to investigate the criminality of immigrants. As we have seen, domestic police had been apprehensive of the criminal risk imposed by mass immigration. But as they collected and analysed the statistics of the criminal courts in the 1950 s they were led to the conclusion that not only were immigrants relatively well-behaved, but significant evidence emerged that their crime rates were generally below those prevailing in the local Australian population.

The Immigration Advisory Council found that immigrants committed crime at half the rate of Australians, and that ethnic groups - such as Southern Europeans - often maligned in the press,

${ }^{47}$ Finnane 2009 
committed very little crime. ${ }^{48}$ Further, police gave evidence that immigrants were often the victims of violent crimes committed by Australians, or reacting to racial provocations. This research on crime and immigration continued throughout the $1950 \mathrm{~s}$, with the results widely publicised in the press. Despite much evidence to the contrary, accusations against immigrants continued throughout the decade, later turning to the conduct of juveniles after an American criminologist remarked that immigrant children were likely to commit future criminal conduct if assimilation was not successful. These remarks sparked another inquiry into immigrant children, which too found that, by and large, immigrant children were not committing crimes or performing worse than their Australian born counterparts. ${ }^{49}$

When immigrants did commit crimes, however, their immigrant status was central to legal and social understandings of their actions. Their immigrant status, drawn upon by defence, was often used to explain their offences - for example, post-war prosecutions for sexual offences saw immigrant men offer cultural explanations for their crimes, drawing on norms in their home country of homosexuality or sexual relations with women. Elsewhere immigrant experiences of war and displacement could also be used to explain violent tendencies and their distrustful interactions with police and other state law enforcement bodies. ${ }^{50}$ For example, in 1954 Estonian immigrant Harald Ruutel committed suicide after he killed his wife, child, mother-in-law and two neighbours (a woman and her child). Ruutel's crimes were explained in the press as 'persecution mania', where he was said to have been so paranoid about the Russians over-running Australia that he killed his family to 'save them from the imagined horrors of occupation'. ${ }^{51}$ Commenting on this case, the Minister for Immigration, Harold Holt, observed that the experience of war led to some immigrants 'breaking down under the added strain of rebuilding their lives' and assured the public that mental health screening of immigrants was robust. ${ }^{52}$ In the 1960s the federal government would order inquiries into the mental health of immigrants, like those in the 1950s about criminal conduct, to quell growing concerns about immigration screening.

\footnotetext{
${ }^{48}$ Finnane and Kaladelfos 2017; Kaladelfos and Featherstone, 2017; Kaladelfos and Finnane 2018 .

${ }^{49}$ Kaladelfos and Finnane 2018.

${ }^{50}$ Kaladelfos and Featherstone, 2017.

${ }^{51}$ Queensland Times, 'Migrant's Letter Explains Killings', 5 April 1954, p.1.

52 Townsville Daily Bulletin, 'Migrant's Health Papers Cleared', 7 April 1954, p.5.
} 
Despite the findings of the inquiries, immigration policy in the 1950 s continued to rely significantly on the criminal law and criminal justice in policing its areas of risk. An unexpected outcome of the Commonwealth inquiry into the criminality of immigrants was the discovery that British-born immigrants were frequently among those found guilty of serious criminal offending, rendering them subject to deportation. In 1951, Sydney's Daily Telegraph reported these findings with the headline 'Criminal Migrants Deported: British at Top of List', citing that since 1948 eighty-two British immigrants had been deported for criminal conduct or being undesirable immigrants, as opposed to fifty-five from other nationalities. ${ }^{53}$ The administration of immigration was still hampered by poor systems of data recording and barriers in communication, so that in at least one notorious instance a deported British sex offender was admitted back into Australia within a couple of years of his deportation only to offend again. The reason he was able to fall through the cracks of the immigration system was the lack of restrictions on the free flow of British immigrants. ${ }^{54}$ The policing of immigration continued to involve the deportation of those caught up in the White Australia policy. The numbers involved were not great in the $1950 \mathrm{~s}$, particularly compared to the volume of incoming immigrants - deportations for illegal entry in the 1950s were never higher in any one year than 253 (1952) and the highest rate of deportations for criminal offending was 128 in 1957.55

As before the war, political risk continued to be an area of concern for those anxious about national security, and the creation of ASIO accentuated this concern. ${ }^{56}$ The powers of exclusion or deportation for political reasons were however tempered by the liberal leanings of even the conservative Menzies government. ${ }^{57}$ While there was certainly a good degree of concern and much noise about the threat of communists and leftists, there were also cases in which these concerns failed to exercise government sufficiently to carry through on threats to deport or block the entry of potential or perceived subversives. Despite the Cold War political

\footnotetext{
53 The Daily Telegraph, 3 November 1951, p.7.

${ }^{54}$ Finnane and Kaladelfos, 2017.

${ }^{55}$ Nicholls 2007.

${ }^{56}$ Horner 2014.

${ }^{57}$ Deery 2005.
} 
climate, the only 'political' exclusion in the first two decades of post-war immigration was in fact that of a British fascist, in $1965 .^{58}$

\section{Beyond crimmigration}

A review of Australian immigration policy and border control suggests the need to reappraise some key features of the crimmigration thesis. In the light of this history we ask whether the notion of convergence is the most productive way of understanding the contemporary features of immigration policy and border control? In place of convergence we suggest a more historically sensitive framework will be one that acknowledges the interlocking frameworks of immigration law and criminal law, the two being elements of domestic law with their foundation in the sovereignty of a national state. Moreover, there is nothing especially unique about the nation state's expression of its power to define community membership and give effect to that definition through a variety of legal forms and administrative mechanisms. Before the emergence of modern immigration law, the notion of one's domicile defined the obligations of the community to support its members and of other communities to remove the unwanted back to their original communities. The fundamental feature of the English poor law was the notion of membership of a defined community by reason of birth or other recognition by that community, combined with an obligation of that community to support its own. Significantly the poor law was also closely linked historically with the challenge of vagrancy, that is the problematisation of economically or socially rootless individuals who were subject to drastic legal sanctions when they were outside the boundaries of their community. ${ }^{59}$ In this respect the perceived 'undesirability' of particular populations of immigrants replicates more longstanding exclusions of outsiders. ${ }^{60}$

The point here is to consider whether it is conceivable for a sovereign community to define the conditions of membership of that community free of criminal sanctions or at least those sanctions which necessarily embody punitive consequences of detention or exclusion. And our

\footnotetext{
${ }^{58}$ Terence Robson, a British fascist, initally accepted as an assisted migrant with his wife and two children, was subsequently refused entry owing to his political associations: P R Heydon to the Minister for Immigration [Billy Snedden], 21 December 1966, Security screening British migrants - policy - Part 1, NAA A6980, S250772.

${ }^{59}$ Aliverti 2015, p. 17.

${ }^{60}$ See eg the numerous European and North American nineteenth-century examples reviewed in Fahrmeir, Faron, and Weil, 2003.
} 
review of the changing contours of Australian immigration policy suggests that the quantum of sanctions exercised against unlawful arrivals is best understood through the broadest consideration of macroeconomic or global conditions, as well as the local socio-economic status of the local community. The striking contrast of the last seventy years of the post-war immigration boom in Australia is the comparison of the 1950s when Australia (relatively speaking) received its greatest numbers of immigrants and (again relatively speaking) used its powers of exclusion and other sanctioning minimally, when compared with the last 20 years or so when both global conditions and domestic political pressures have provided a much less welcoming climate. ${ }^{61}$ The criminal law and immigration law were already there in the $1950 \mathrm{~s}$ to be deployed - and had the conditions, political and global, required, then 'crimmigration' was already in waiting.

${ }^{61}$ For a striking nineteenth-century example of the impact of global conditions on domestic migration policy seee Zolberg's study of the hardening of state laws in the US in the face of mass Irish and other European immigration in the 1850s, Zolberg, 2003. 


\section{Reference List}

Aliverti, Ana. "The Wrongs of Unlawful Immigration." Criminal Law and Philosophy 11, no. 2 (June 1, 2017): 375-91. https://doi.org/10.1007/s11572-015-9377-y.

Aliverti, Ana. 2012. "Making People Criminal: The Role of the Criminal Law in Immigration Enforcement." Theoretical Criminology $16 \quad$ (4): 417-34. https://doi.org/10.1177/1362480612449779.

Aliverti, Ana. 2015. Crimes of Mobility: Criminal Law and the Regulation of Immigration. 1 edition. Abingdon, Oxon ; New York, NY: Routledge.

Andrew, C. M. 2009. The Defence of the Realm: The Authorized History of MI5. Lane, Allen. Bailkin, Jordanna. 2012. The Afterlife of Empire. Berkley; University of California.

"Barker, Tom." 1919. Adelaide. D1921, 1919/53. National Archives of Australia. http://www.naa.gov.au/cgi-bin/Search?O=I\&Number=328785 (accessed 26 Jan 2019).

Bashford, Alison, and Carolyn Strange. 2002. "Asylum-Seekers and National Histories of Detention." Australian Journal of Politics and History 48 (4): 509-27.

Bashford, Alison, and Sarah Howard. 2004. 'Immigration and Health: Law and Regulation in Australia, 1901-1958.' Health and History 6, no. 1: 97-112.

Bashford, Alison. 2002. 'At the border contagion, immigration, nation'. Australian Historical Studies, 33 (120): 344-358

Bashford, Alison. 2004. Imperial Hygiene: A Critical History of Colonialism, Nationalism and Public Health. Houndsmills [England]; New York: Palgrave Macmillan.

Bergantz, Alexis. 2018. “"The Scum of France': Australian Anxieties towards French Convicts in the Nineteenth Century." Australian Historical Studies 49 (2): 150-66. https://doi.org/10.1080/1031461X.2018.1452951.

Burgmann, Verity. 1995. Revolutionary Industrial Unionism : The Industrial Workers of the World in Australia. Cambridge, UK; New York: Cambridge University Press.

Cain, Frank. 1983. The Origins of Political Surveillance in Australia. Sydney: Angus \& Robertson.

Cole, Simon A. 2001. Suspect Identities: A History of Fingerprinting and Criminal Identification. Cambridge, MA: Harvard University Press.

Cresciani, Gianfranco. 1980. Fascism, Anti-Fascism, and Italians in Australia, 1922-1945. Canberra; Trumbull, Conn.: Australian National University Press.

Day, David. 1996. Contraband \& Controversy: The Customs History of Australia from 1901. Canberra: AGPS Press. 
Deery, Phillip. 2005. “'Dear Mr. Brown': Migrants, Security and the Cold War.” History Australia 2 (2): 40-1:40-12.

Dutton, David. 1998. "The Commonwealth Investigation Branch and the Political Construction of the Australian Citizenry, 1920-40." Labour History 75: 155-74.

Dutton, David. 2002. One of Us? : A Century of Australian Citizenship. Sydney: UNSW Press. Fahrmeir, Andreas, Olivier Faron, and Patrick Weil, eds. Migration Control in the North Atlantic World: The Evolution of State Practices in Europe and the United States from the French Revolution to the Inter-War Period. New York: Berghahn Books, 2003.

Farmer, Lindsay. “Thinking about (Hidden) Criminalisation.” Text. International Journal for Crime, Justice and Social Democracy, September 1, 2018. https://doi.org/10.5204/ijcjsd.v7i3.556.

Farmer, Lindsay. 2016. Making the Modern Criminal Law: Criminalization and Civil Order. Finnane, Mark, and Andy Kaladelfos. 2017. "British Migrants, Criminality and Deportation: Shaping the Australian Post-War Approach." The Journal of Imperial and Commonwealth History 45 https://doi.org/10.1080/03086534.2017.1294240.

Finnane, Mark, and John Myrtle. 2011. "An Exercise in Police Co-Operation? The Origins of the Conference of Australian Police Commissioners." Australian Journal of Politics \& History 57 (1): 1-16. https://doi.org/10.1111/j.1467-8497.2011.01579.x.

Finnane, Mark. 2007. J V Barry: A Life. Sydney: UNSW Press.

Finnane, Mark. 2009. “Controlling the 'Alien' in Mid-Twentieth Century Australia: The Origins and Fate of a Policing Role." Policing and Society 19 (4): 442-67.

Finnane, Mark. 2010. "National Security and Immigration in Australia's Twentieth Century History." Australian Policy and History. http://aph.org.au/national-securityimmigration.

Finnane, Mark. 2013a. "Deporting the Irish Envoys: Domestic and National Security in 1920s Australia." Journal of Imperial and Commonwealth History 41 (3): 403-25.

Finnane, Mark. 2013b. "Law as Politics: Chinese Litigants in Late Colonial Court-Rooms." Journal of Chinese Overseas 9 (2): 193-211.

Finnane, Mark. 2014. “'Habeas Corpus Mongols'-Chinese Litigants and the Politics of Immigration in 1888." Australian Historical Studies 45 (2): 165-83. https://doi.org/10.1080/1031461X.2014.911759. 
Fischer, Gerhard. 1989. Enemy Aliens: Internment and the Homefront Experience in Australia. St. Lucia, Qld: University of Queensland Press.

Frances, Raelene. 2007. Selling Sex: A Hidden History of Prostitution. Sydney: UNSW Press. Gatrell, Vic. 1990. 'Crime, authority and the policeman-state'. In F. Thompson (Ed.), The Cambridge Social History of Britain, 1750-1950 Cambridge: Cambridge University Press: 243-310.

Ham, Julie, and Sharon Pickering, eds. 2015. The Routledge Handbook on Crime and International Migration. Routledge International Handbooks. London: Routledge.

Henderson, Gerard. 1976. "The Deportation of Charles Jerger." Labour History, no. 31 (November): 61-78. https://doi.org/10.2307/27508238.

Horner, D. M. 2014. The Spy Catchers. Volume I : The Official History of ASIO, 1949-1963. Crows Nest, NSW: Allen \& Unwin.

Kaladelfos, Amanda. 2010. 'Crime and outrage: Sexual villains and sexual violence in New South Wales, 1870-1930', PhD, University of Sydney.

Kaladelfos, Andy, and Lisa Featherstone. 2017. 'Race and Ethnicity in Sex Crimes Trials'. In Robert Mason ed. Legacies of Violence in Modern Australia. Berghahn Publishing: 217-232.

Kaladelfos, Andy, and Mark Finnane. 2018. "Immigration and Criminality: Australia's PostWar Inquiries." Australian Journal of Politics \& History 64 (1): 48-64. https://doi.org/10.1111/ajph.12425.

Kimber, Julie. 2013. 'Poor Laws: A Historiography of Vagrancy in Australia.' History Compass 11: 537-50.

Kuo, Mei-Fen, and John Fitzgerald. 2016. "Chinese Students in White Australia: State, Community, and Individual Responses to the Student Visa Program, 1920-25." $\begin{array}{lllll}\text { Australian } & \text { Historical } & \text { Studies } & 47 & \text { (2): }\end{array}$ https://doi.org/10.1080/1031461X.2016.1156136.

L'Estrange, P. n.d. “Jerger, Charles Adolph (1869-1927)." In Australian Dictionary of Biography. Canberra: National Centre of Biography, Australian National University. Accessed June 19, 2018. http://adb.anu.edu.au/biography/jerger-charles-adolph-6843. Lacey, Nicola. "Historicising Criminalisation: Conceptual and Empirical Issues." The Modern Law Review 72, no. 6 (2009): 936-60. https://doi.org/10.1111/j.14682230.2009.00775.x. 
Lacey, Nicola. "Theorising Criminalisation through the Modalities Approach: A Critical Appreciation.” Text. International Journal for Crime, Justice and Social Democracy, September 1, 2018. https://doi.org/10.5204/ijcjsd.v7i3.557.

Lake, Marilyn, and Henry Reynolds. 2008. Drawing the Global Colour Line: White Men's Countries and the Question Of. Carlton, Vic: Melbourne University Publishing.

Macintyre, Stuart. 2015. Australia's Boldest Experiment: War and Reconstruction in the 1940s. Sydney: New South Publishing.

Markus, Andrew. 1979. Fear and Hatred: Purifying Australia and California, 1850-1901. Sydney: Hale \& Iremonger.

Martens, Jeremy. 2006. 'A Transnational History of Immigration Restriction: Natal and New South Wales, 1896-97'. The Journal of Imperial and Commonwealth History, 34 (3): 323-344.

Mountford, Benjamin. 2016. Britain, China, and Colonial Australia. Oxford University Press. http://www.oxfordscholarship.com/view/10.1093/acprof:oso/9780198790549.001.000 1/acprof-9780198790549.

Neumann, Klaus, and Gwenda Tavan, eds. 2009. Does History Matter?: Making and Debating Citizenship, Immigration and Refugee Policy in Australia and New Zealand. ANZSOG Series. Canberra: ANU E Press. http://epress.anu.edu.au/.

Neumann, Klaus. 2004. Refuge Australia: Australia's Humanitarian Record. Sydney: UNSW Press.

Neumann, Klaus. 2006. In the Interest of National Security: Civilian Internment in Australia during World War II. Canberra: National Archives of Australia.

Neumann, Klaus. 2015. Across the Seas: Australia's Response to Refugees a History. Collingwood: Black Inc.

Ngai, Mae M. 2004. Impossible Subjects: Illegal Aliens and the Making of Modern America. Politics and Society in Twentieth-Century America. Princeton, N.J: Princeton University Press.

Nicholls, Glenn. 2007. Deported: A History of Forced Departures from Australia. Sydney, N.S.W.: UNSW Press.

Petrow, S. 2012. "Convict-Phobia": Combating Vandemonian Convicts in 1850s and 1860s Victoria." Journal of Australian Colonial History 14: 260-71.

Pickering, Sharon, and Leanne Weber. 2013. "Policing Transversal Borders." In The Borders of Punishment: Migration, Citizenship, and Social Exclusion. Oxford University Press. 
http://www.oxfordscholarship.com/view/10.1093/acprof:oso/9780199669394.001.000 1/acprof-9780199669394-chapter-6.

Rodriguez, Julia. 2006. Civilizing Argentina: Science, Medicine, and the Modern State. Chapel Hill: University of North Carolina Press.

Rosenberg, Clifford D. 2006. Policing Paris: The Origins of Modern Immigration Control Between the Wars. Ithaca, N.Y: Cornell University Press.

Rosenbloom, Rachel E. 2016. “Policing Sex, Policing Immigrants: What Crimmigration's Past Can Tell Us about Its Present and Its Future.” California Law Review 104: 149200.

Saunders, Kay. 1992. War on the Homefront: State Intervention in Queensland 1938-1948. UQP Studies in Australian History. St. Lucia, Qld: University of Queensland Press. Slaven, Mike, and Christina Boswell. "Why Symbolise Control? Irregular Migration to the UK and Symbolic Policy-Making in the 1960s." Journal of Ethnic and Migration Studies, April 9, 2018, 1-19. https://doi.org/10.1080/1369183X.2018.1459522.

Smith, Jean P. 2018. 'From Promising Settler to Undesirable Immigrant: The Deportation of British-born Migrants from Mental Hospitals in Interwar Australia and South Africa'. The Journal of Imperial and Commonwealth History, 46 (3): 502-523.

Speedy, Karin. 2016. ““Arab Castaways’/‘French Escapees”: Mobilities, Border Protection and White Australia." Law, Crime and History 6 (2): 15-30.

Stewart, Iain; Hohmann, Jessie and Robertson, Kel. 2005. 'Dictating to One of 'Us': The Migration of Mrs Freer'. Macquarie Law Journal, 5: 241-275

Stumpf, Juliet. "Crimmigration: Encountering the Leviathan." In The Routledge Handbook on Crime and International Migration, edited by Sharon Pickering and Julie Ham, 237-50. Routledge, 2014.

Tavan, Gwenda. 2005. The Long, Slow Death of White Australia. Carlton North, Vic: Scribe Publications.

Torpey, John C. 2000. The Invention of the Passport: Surveillance, Citizenship, and the State. Cambridge Studies in Law and Society. Cambridge [England]: Cambridge University Press.

Turner, Ian. 1969. Sydney’s Burning. Rev. Sydney: Alpha Books.

Weiner, Tim. 2013. Enemies: A History of the FBI. New York: Random House. 
Whitaker, Reginald, Gregory S Kealey, and Andrew Parnaby. 2012. Secret Service: Political Policing in Canada from the Fenians to Fortress America. Toronto, Ontario: University of Toronto Press.

Zedner, Lucia. 2013. 'Is the Criminal Law Only For Citizens? A Problem at the Borders of Punishment' in Franko K. and Bosworth M. (Eds). The Borders of Punishment: Migration, Citizenship and Social Exclusion. Oxford: Oxford University Press: 40-57. Zogbaum, Heidi. 2004. Kisch in Australia: The Untold Story. Carlton North, Vic: Scribe Publications.

Zolberg, Aristide R. "The Archaeology of 'Remote Control." In Migration Control in the North Atlantic World: The Evolution of State Practices in Europe and the United States from the French Revolution to the Inter-War Period, edited by Andreas Fahrmeir, Olivier Faron, and Patrick Weil. New York: Berghahn Books, 2003. 